\title{
Various Language Expressions in The Criticism of Madurese People on Social Media Field
}

\author{
Akhmad Sofyan \\ Faculty of Cultural Science, Universitas Jember \\ email: sofyanakhmad544@gmail.com \\ Panakajaya Hidayatullah \\ Faculty of Cultural Science, Universitas Jember \\ email: panakajaya.hidayatullah@gmail.com \\ Ali Badrudin \\ Faculty of Cultural Science, Universitas Jember \\ email: elbadrelkarim@yahoo.com
}

\begin{abstract}
The Madurese community in Situbondo is a group of people who are still 'unfamiliar' with the internet media (social media). Their lack of understanding in using social media often creates problems in society. This article is the result of ethnography of communication research which discusses criticism behavior of Madurese people in Situbondo in social media. It comprehensively analyzes aspects of use of language choice, motive of language choice and language formulation expressed by informants. Research findings show that: 1) Situbondo people express criticism in social media by using code of Madurese language and mixed Madurese-Indonesia and Madurese-English, and they are expressed through some patterns which are humor, figurative, threatening and affirmative, direct and indirect satire, Kiyai quote and lyrical/poetical pattern; 2) Some motives background of choice of language code in expressing criticism are influenced by aspects of hierarchy in a context of diglosia society, politic of identity; dimension of ethnic group and psychological and cultural motives. Formulation of these findings
\end{abstract}


explain that most of criticism model of Madurese people in Situbondo through social media is manifestation of habit in expressing criticism in real world. Something avoided is criticism model using sarcasm sentence, containing hate speech, offending pride, social status, family and feeling of interlocutors. Expressive and outspoken criticism in social media are also considered to be dangerous and unacceptable by people because they create 'floating' (unclear) interpretation, and potential to be misinterpreted. While some acceptable criticism are criticism model expressed by fine language and expressed by humor, figurative, fine satire and lyrical/poetical patterns.

[Masyarakat Madura di Situbondo merupakan kelompok masyarakat yang masih "awam" dengan media internet (media sosial), ketidakmengertian dalam menggunakan media sosial seringkali menimbulkan masalah di masyarakat. Artikel ini merupakan hasil penelitian etnografi komunikasi yang membahas perihal perilaku kritik masyarakat Madura di Situbondo dalam media sosial. Secara komprehensif menelaah tentang aspek penggunaan pilihan bahasa, alasan pemilihan bahasa, dan formulasi bahasa yang diperagakan oleh informan. Temuan penelitian menunjukkan bahwa: 1) masyarakat Situbondo menyampaikan kritik di media sosial menggunakan kode bahasa Madura dan campuran, Madura-Indonesia dan Madura-Inggris, serta diekspresikan melalui beberapa pola yaitu pola humor, pola kiasan, pola ancaman dan penegasan, pola sindiran langsung dan tidak langsung, pola kutipan Kiyai serta pola lirisi/puitik; 2) Beberapa alasan yang melatarbelakangi pemilihan kode bahasa dalam menyampaikan kritik ialah dipengaruhi oleh aspek hirarki bahasa dalam konteks masyarakat diglosia, politik identitas, dimensi kelompok etnik serta alasan psikologis dan budaya. Formulasi dari temuan tersebut menjelaskan bahwa sebagian besar model kritik masyarakat Madura di Situbondo melalui media sosial merupakan ejawantah dari kebiasaan dalam menyampaikan kritik di dunia nyata. Perihal yang dihindari yaitu model kritik yang menggunakan kalimat sarkasme, mengandung ujaran kebencian, menyinggung harga diri, status sosial, keluarga serta perasaan lawan tuturnya. Kritik yang ekspresif dan blak-blakan di media sosial juga dianggap berbahaya dan tidak diterima oleh masyarakat karena menciptakan penafsiran yang 'mengambang' (tidak jelas), dan berpotensi untuk disalah-tafsirkan. Sementara beberapa kritik yang bisa diterima ialah model kritik yang disampaikan dengan kode bahasa halus, dan diekspresikan dengan pola humor, kiasan, sindiran halus, serta pola liris (puitis).]

Keywords: criticism; Madurese people; social media; Situbondo 


\section{Introduction}

Diaspora of Madurese people to various areas in Indonesia is not only going naturally. Instead of getting proper place and hospitality by people in migration area, Madurese people are often made 'scapegoat' and source of problems in some social problems. Process of cultural interaction is not going harmoniously, one of cases is caused by cultural disagreement in society. Incomprehensive understanding of people and Madurese culture then crystallize to be negative discourse (stereotype). This stereotype then becomes basis for justifying characteristics of an ethnic group and it is often used as instrument in contestation of identity discourse (politic of identity) of people. If there is no effort to reveal Madurese culture comprehensively, therefore the discourse is going continuously and then established and legitimized by people as absolute truth.

Something fundamental of emergence of any conflict happened is a fail of social interaction process in society. Madurese people have unique values and norms such as ethics in expressing criticism. Communication (criticism) norms in process of social interaction does not only apply in public field, but also in domestic field. Madurese people have their own norms like how is interaction in relation of household, relatives and neighborhood. In process of social interaction, there are normal and taboo things prohibited to do. If these are violated, social conflict will happen. Today, expressing criticism by Madurese people is not understood as criticism happened in context of 'real' world, but also in 'virtual' world. In era of globalization and transparent of information technology today, cross cultural and society ethnic are no longer limited by geography. Interaction process becomes inevitable necessity directly (physically) or indirectly (by means of online media like internet).

For Madurese people in Situbondo, online media (internet/social media) is something new, but it has developed rapidly. Based on the writer's observation ${ }^{1}$, most of families in village areas in Situbondo already have social media accounts like Facebook and Whatsapp. The

\footnotetext{
${ }^{1}$ Observation for a year in 2018. The last is done in some villages in Situbondo and interviewing some informants in those villages.
} 
use of social media by village people generally is not a very important need, but it is just means of self-expression, to search information in local groups like 'Info Warga Situbondo' (Information of Situbondo people) and 'Info Jual Beli Situbondo' (Information of Situbondo Trade), and also to greet relatives. It can be said that social media is new media for most of Madurese people in Situbondo. Therefore no wonder, when its function and benefit have not been felt optimally by people

Instead of getting benefit from social media, most of Madurese people in Situbondo get many social problems with this new social media. One that can be analyzed is about expressing criticism, about how criticism is expressed in social media status. Madurese people in Situbondo are using social media, one of them, as means of expressing criticism, in the form of firm, satire or fine criticism (figuratively). Madurese people habits which are expressive and outspoken in 'real' world unconsciously also color their social media, until it often triggers conflict. Incomprehension about social media and norms in social media often becomes boomerang for Madurese people in Situbondo. Some cases like abuse of Kiyai and religion in Situbondo also happen because of criticism of netizen in social media. ${ }^{2}$

It is necessary to know that Madurese people in Situbondo are quite complex and have different characteristics to Madurese people in Madurese island. The complexity, for example, is described in use of language as daily communication. Generally, Madurese people in Situbondo are divided into two areas, who are Madurese language speakers (ML) with Tèmor dialect in East Situbondo (Melandingan Banyuputih) and Madurese language speakers (ML) with Bârâ' dialect in West Situbondo (Banyuglugur - Melandingan). The difference of dialect is influenced by historical factor of Madurese migration to Situbondo. Eeast Situbondo is migration area of Madurese Sumenep people, while the west is migration area of Madurese Pamekasan people. ${ }^{3}$ Besides, in Situbondo, there is also various Madurese language

\footnotetext{
${ }^{2}$ See:https://imadetik.com/akibat-medsos-pria-asal-situbondo-berurusan-denganhukum/, accessed on $26^{\text {th }}$ November 2018.

3 Panakajaya Hidayatullah, Dangdut Madura Situbondoan (Yogyakarta: Diandra Kreatif, 2017).
} 
as result of Madurese cultural appropriation process with other culture. Process of appropriation results mixed language Madurese-Indonesia, Madurese-Java, Cak Labik (mixed reversed language) and use of ondâgghâ bhâsa $a^{4}$ which is often irregular.

This research is ethnography of communication. Specifically, it will discuss use of criticism in social media by Madurese people in Situbondo. Focus of this research will analyze about how Madurese Situbondo people express their criticism through social media. The analysis will discuss 1) choice of language; and 2) motives of language use. This research is done to dig up and understand current phenomena of Madurese people in Situbondo especially in responding change of era (modernity) by means of social media and as an effort to minimalize occurrence of social conflict caused by cultural misunderstanding.

\section{Methods}

Understanding interaction process of Madurese people cannot be done through common perspective and approach. It needs approach and method of research which are participatory and experimental. This research is using multidisciplinary approach which explores perspectives of cultural anthropology and linguistic through ethnography of communication method. Ethnography of communication method is a way to study and explain phenomena based on ethnography principle, so it will get description about phenomena of communication ethnographically. ${ }^{5}$ Ethnography means description, exposure and explanation about culture and culture of people, such as

4 Soegianto, Unda-Usuk Bahasa Madura (Jakarta: Pusat Pembinaan dan Pengembangan Bahasa Departemen Pendidikan dan Kebudayaan, 1997); Akhmad Sofyan, Variasi, Keunikan, dan Penggunaan Bahasa Madura (Surabaya: Balai Bahasa Surabaya, 2008); A. Sukardi, Kasusastraan Madura Kembang Sataman (Jember: Dinas Pendidikan Kabupaten Jember, 2001).

5 Bambang Wibisono, Etnografi Komunikasi Dalam Penelitian Perilaku Berbahasa (Jember: Jember University Press, 2007), 69. 
customs, habit, law, art, religion, language and others like done by ethnolog and ethnographer. ${ }^{6}$

This research procedure of ethnography of communication uses Developmental Research Sequence. This research goes with stages 1) Participatory Observation (in social media and lived cultural approach; 2) Record (recording data in social media and direct interview; 3) ethnographic note; 4) Deep interview with informants. This research procedure also refers to ethnography method by Spradley. ${ }^{7}$ The chosen informants which become research subjects are active netizen of social media who have background of Madurese Situbondo culture. The researcher is browsing to some local Facebook group dominated by Situbondo people like Info Warga Situbondo (Information of Situbondo people) and observing their interaction inside. Some chosen informants are then observed about their interaction in social media like update status, comments and share content. This observation is done secretly. After collecting some data, the researcher is then approaching personally and doing deep interview to clarify the previous data and dig up deeper information of ethnography. Some collected data are then transcribed and analyzed in accordance with the research aims and problems.

\section{Results}

\section{Language Choice of Criticsm In Social Media}

Language behavior is language activity by someone when he/she faces certain situation of communication. ${ }^{8}$ Language behavior is realized in some sub-activities like 1) choice of language code (language

\footnotetext{
6 A. Marzali, Apakah Etnografi. In Metode Etnografi (Yogyakarta: Tiara Wacana, 1997).

7 J. P. Spradley, Participant Observation (New York: Hold, Rinehart and Winston, 1980).

8 J. F. Hamers, Bilinguality and Bilingualism (Cambridge: Cambridge University Press, 1995); J. Holmes, An Introduction to Sociolinguistics (London: Longman Group UK Limited, 1997); M. Savile-Troike, (The Ethnography of Communication. New York: Basil Blackwell Ltd, 1989); Bambang Wibisono, Etnografi Komunikasi Dalam Penelitian Perilaku Berbahasa (Jember: Jember University Press, 2007),
} 
choice, code selection, code choice, code switching, code mixing, and code borrowing); 2) style shifting; and 3) turn taking. ${ }^{9}$ Specifically, language behavior can be narrowed and it refers to activity to understand language choice, code shifting, mixed code, style shifting and turn speaking shifting. In criticism activities of Madurese people in Situbondo in social media, there are also some language choices. This article focusses on discussing two things which are 1) mixed code 2) various of language expression. Here is the data explanation.

\section{Mixed Code}

Language choice cannot only be tied to use of language code in single language (same), but it can also shift and mix to language code from different language. ${ }^{10}$ Like explained in previous chapter, Madurese people in Situbondo are very complex. Cultural appropriation which has lasted long results various language product, one of them is various mixed language. In language behavior, various mixed language is called mixed code. In context of criticism of Madurese people in Situbondo in social media, various mixed language are often founded and it becomes unique social identity of Situbondo people. Here is the analysis.

\section{a. Madurese - Indonesia}

9 J. F. Hamers, Bilinguality and Bilingualism (Cambridge: Cambridge University Press, 1995).

${ }^{10}$ Bambang Wibisono, Etnografi Komunikasi Dalam Penelitian Perilaku Berbahasa (Jember: Jember University Press, 2007), 11. 


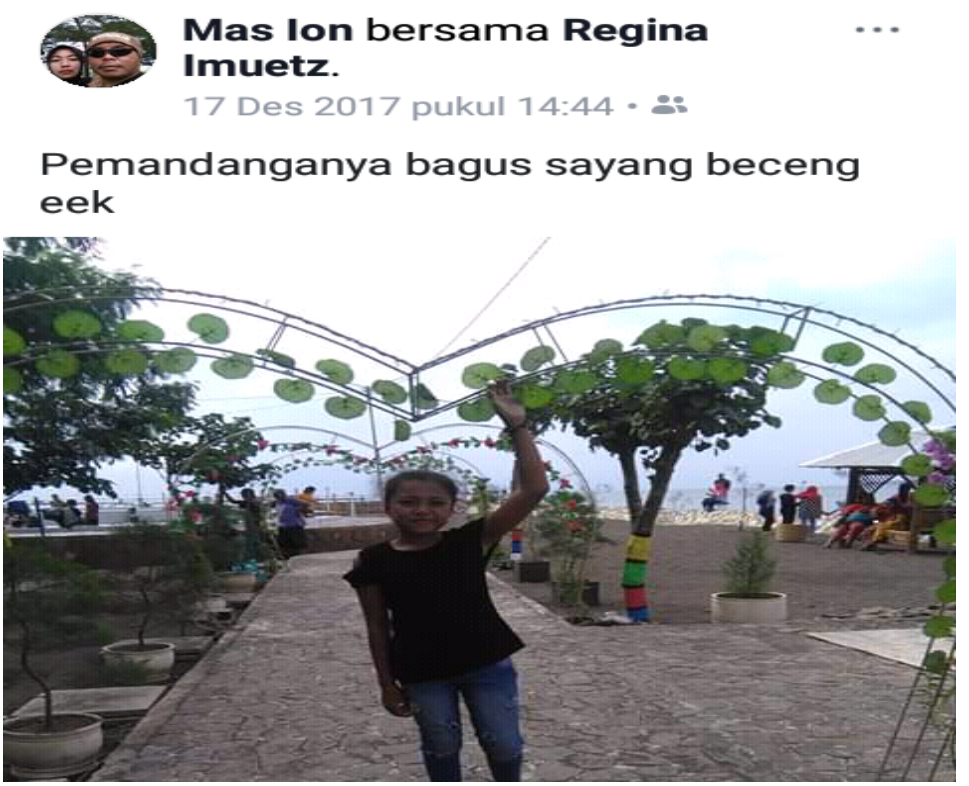

Picture 1. Mixed language Madurese-Indonesia Source: Personal Documentation

"Pemandangannya bagus, sayang bâceng è̀̀"

(The view is good but smelled animal waste).

The picture above is an example of criticism using various mixed language Madurese-Indonesia. In Situbondo, there are many mixed language Madurese-Indonesia found, so it becomes identity character of Situbondo people (see Hidayatullah, 2017). Context of the picture is a person (Iyon) in vacation with his family in Grand Patek (GP) beach, in Gelung village, Panarukan sub-district, Situbondo district. GP is a new tourist destination in Situbondo managed by village government. Its condition is new and there are many lacks, which make Iyon feel uncomfortable. One of problems is that GP is surrounded by cowshed owned by local villagers. Iyon's disappointment is then expressed by himself by means of status of social media facebook. Intentionally, Iyon captures picture of the destination location and gives caption of criticism 
to tourism manager. It needs to know that various mixed language Madurese - Indonesia is various mixed code which is the most frequently used by Situbondo people rather than other various mixed language. It is different to Jember which has dominant mixed language Javanese-Madurese. ${ }^{11}$

\section{b. Madurese - English}

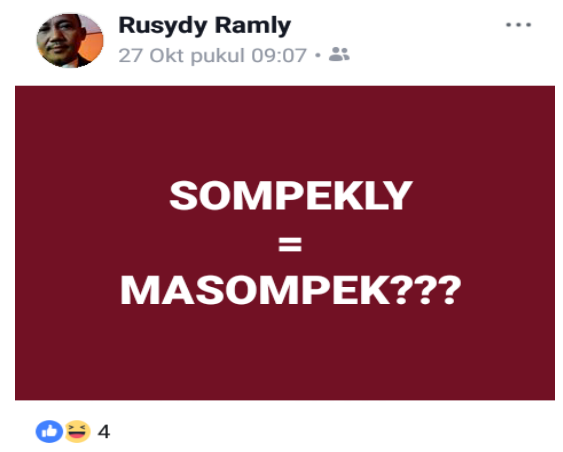

Picture 2. Mixed language Madurese - English

Source: Personal Documentation

$$
\begin{gathered}
\text { Sompekly = Masompek } \\
\text { (boring) }
\end{gathered}
$$

The picture above is an example of criticism in using mixed language Madurese - English. It needs to explain that context of the status is written to respond tagline of tourism promotion launched by Situbondo regency government that sounds "SUPRISINGLY SITUBONDO". Here is the tagline picture.

11 Bambang Wibisono, (2007). "Faktor Penentu Pemilihan Varian Bahasa oleh Multibahasawan Etnis Madura di Jember dalam Obrrolan”. Humaniora 19, no. 1 (2007): 52-61, https://doi.org/10.22146/jh.v19i1.891 

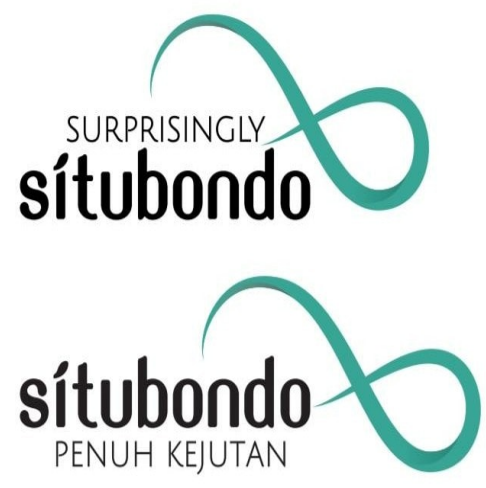

\section{Picture 3. Tagline of Situbondo tourism \\ Source: Personal Documentation}

The tagline is improper in English grammar. Rusdi, the critical writer in social media facebook is a member of Regional Research Council of Situbondo who has academic background of English literature. Rusdi feels embarrassed with careless regency government that hastily makes an English tagline. His disappointment is then expressed through his social media status by making play words using Madurese in English grammar. Annoyed Rusdi does not only make a play in one status, but more than ten status containing satire to Situbondo government.

\section{Various Language Expression}

This sub chapter will explain model, pattern and various language expression of Madurese people related to criticism expression in social media. Criticism of Madurese Situbondo people in social media has many forms and patterns. Here will be explained one by one.

\section{a. Humor Pattern}




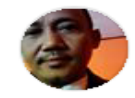

\section{Rusydy Ramly}

31 Okt pukul 16:40 - :

\section{EPPAK KASOLY NAAAK... EPPAK ROWETLY CONG... EPPAK KATONDULY.....}

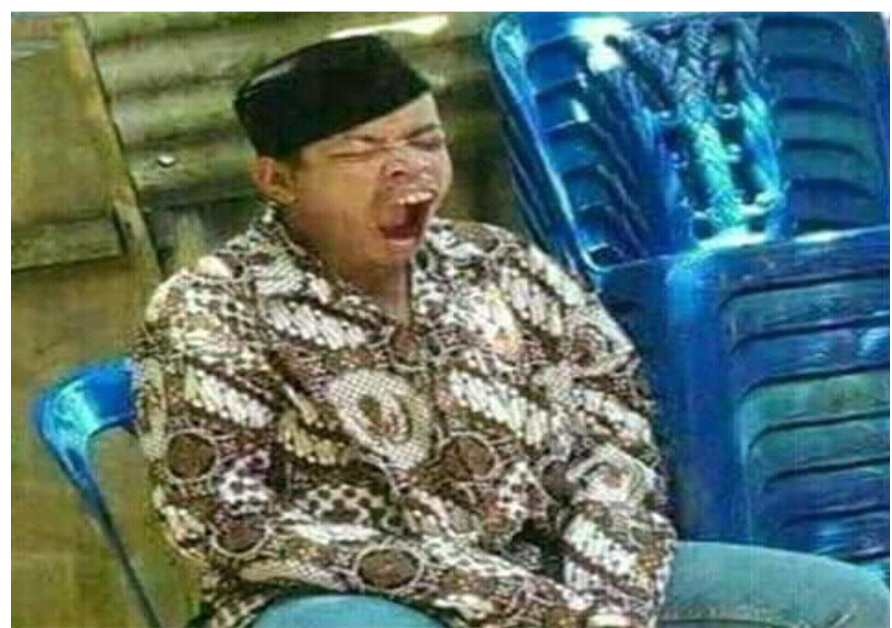

Picture 4. Humor Pattern

Source: Personal Documentation

“Eppa' kasoly nak, eppa' rowetly nak, eppa' katonduly" (Dad is tired, kid, Dad is stressed, kid, Dad is sleepy)

The picture above shows an example of criticism expressed by using humor pattern. Context of the picture is still the same to previous explanation which is satire to government policy carelessly in making tourism tagline in English. Humor pattern of play text is related to picture uploaded together. So the content becomes funny, satirical and interesting. The criticism using humor pattern is criticism pattern which is the most frequently used by Madurese people in Situbondo. This pattern is usually used by teenagers to satirize each other through meme, or adults who are clever to make joke and play. 


\section{b. Figurative Pattern}

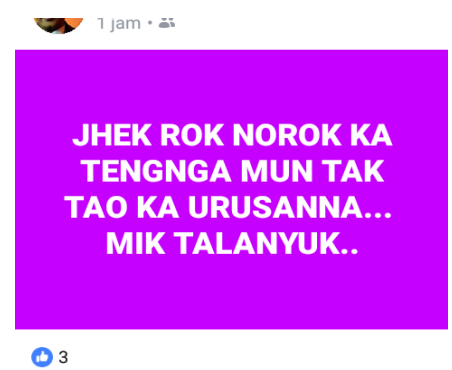

Picture 5. Figurative Pattern

Source: Personal Documentation

“jhâ' ro' noro' ka tengnga mon ta' tao ka urusanna, mi' talanyo","

(Do not follow to center if do not understand the matters, afraid of washed away)

The picture above is an example of criticism using figurative pattern in which the true meaning is hidden by the speaker. Context of the criticism means that 'if you do not really understand a matter, do not intervene so it cannot be fatal consequences'. Criticism through use of figurative pattern is rare to use by Madurese people in Situbondo, because it looks difficult and needs ability to process feeling and thought in arranging sentence. This criticism model is usually used to satirize person or group in a fine way. The object and intention are disguised, so it cannot cause conflict in society.

The context of the figurative expression written by Rusdi is a figure that describes the background of the ocean. The expression is actually a cultural expression that often appears in poems and songs of the Madurese community. The song Olè Olang, Tandu 'Majâng, and Duh Angin is an example of some Madurese songs that describe the background of the ocean, then the expression Abhântal Ombâ', Asapo 'Angin (bearing waves, covered in wind) is a real picture of the life experience of Madurese people who are very close to coastal culture. Zawawi Imron's poetry entitled Fishermen's humming and sea travel 
also illustrates how the Madurese people live. ${ }^{12}$ This explains that through figurative speech Madurese people we can read the nature of thought, experience and cultural expressions.

\section{c. Threatening and Affirmative Pattern.}

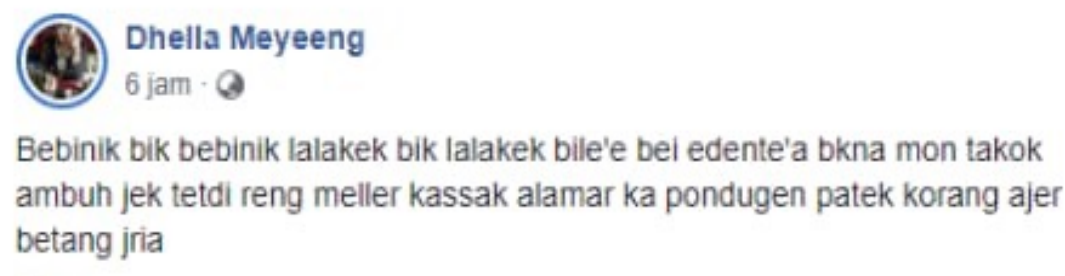

Picture 6. Threatening and Affirmative Pattern

Source: Personal Documentation 'Bâbini' bi' bâbini', lalakè' bi' lalakè' , bilâ bhâi èdântè'a bâ'na, mon tako' ambuh jhâ' dhâddhi rèng meller. Kassa' alamar ka pondhughân, Patè', korang ajhâr bhâtang jârèya" (Fellows women or men, I will wait anytime. If scared, do not become bad people. Just go applying to Islamic Boarding School. Damn dog).

The picture above is an example of criticism model with threatening and affirmative pattern. This kind of criticism is the harshest and avoided to express, because it potentially triggers social conflict in society. Commonly, this kind of criticism model is expressed by Senior High School teenager who has labile emotion. It needs to know that model of threatening criticism in Situbondo has reaped many problems and usually, problems in social media will continue to be problems in real world.

12 T. Santoso, "Kajian Sosiobudaya Kumpulan Sajak Madura, "Akulah Darahmu" Karya D. Zawawi Imron”. Humaniora, 16. No. 3 (2004), 313-319. 


\section{d. Satire Pattern}

\section{- Direct satire}

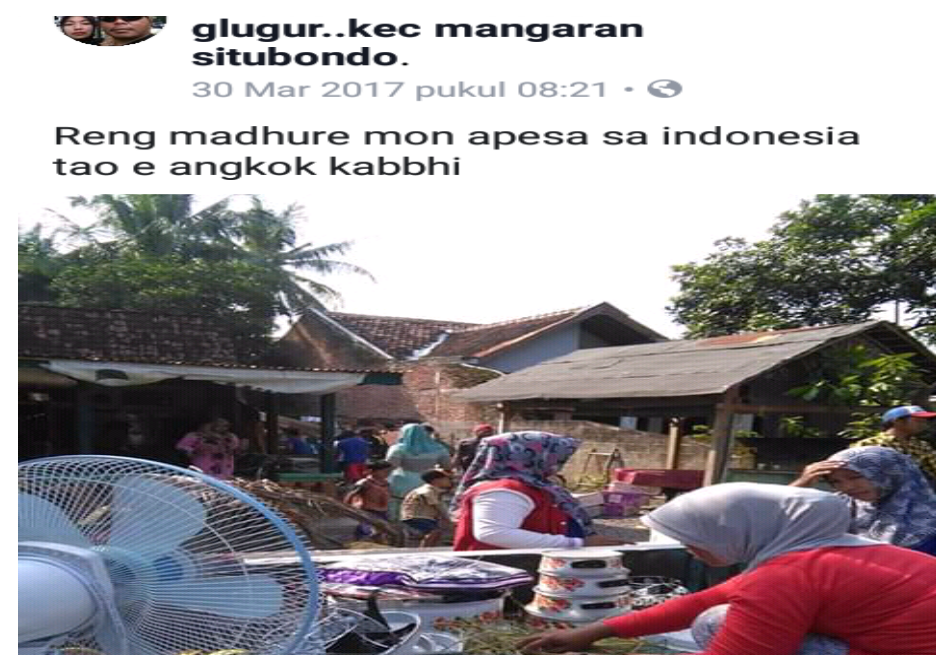

Picture 7. Direct Satire

Source: Personal Documentation

"Rèng Madhurâ mon apèsa sa Indonesia tao, èangko' kabbhi" (If Madurese people are divorced, all Indonesians know, all transported)

The picture above is an example of criticism model of direct satire. In the status, it is included photo documentation and location point. The speaker also knows the person satirized. This kind of satire pattern in Madurese society in Situbondo is often founded, because the people, nota bene, like to communicate with outspoken (frankly) model in satirizing person.

\section{- Indirect Satire}




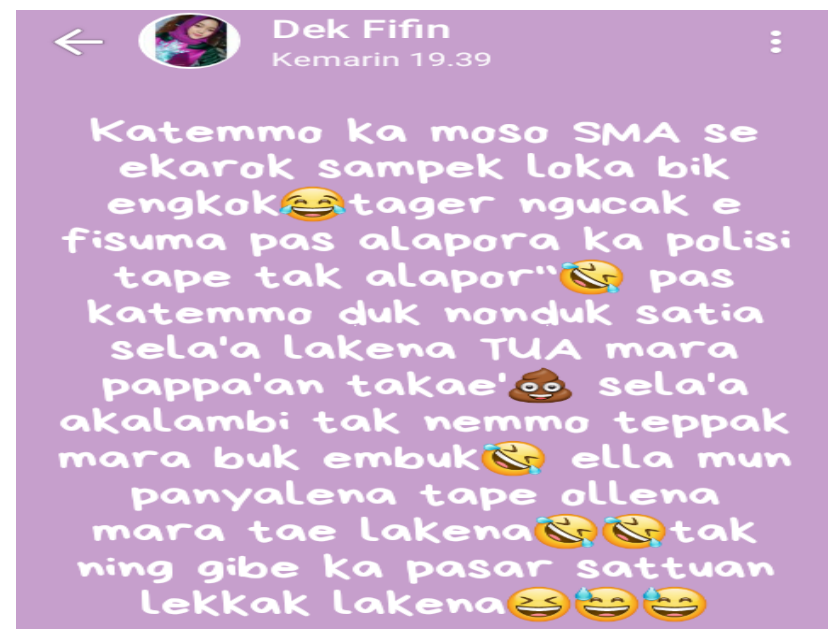

Picture 8. Indirect Satire

Source: Personal Documentation

Katemmo ka moso SMA sè èkaro' sampè 'loka bi' engko', tagher ngoca' è fisuma pas alapora ka polisi, tapè ta' alapor. Pas katemmo du' nondu' satia sèla'a lakèna tua mara pappa'an takaè'. Sèla'a akalambhi ta' nemmo teppa' mara bu' embu'. Ella mun panyalèna tapè ollèna mara taè lakèna. Tak ning ghibâ ka pasar sattoan lekka' lakèna.

(Meet Senior High School enemy I clawed until wounded. Said that it would be examined medically and reported to police, but did not report. When meeting, she looked down. Her husband is old and ugly, dressed wrong like mothers. She can insult but now get ugly husband, even improper to bring to animal market).

Context of that satire above is private status of Whatsapp (WA) which refers to a woman (Senior High School enemy) she hates. Sentence in the satire above is very sarcastic and harsh. The satire above is classified to indirect satire because the woman as satirized object actually cannot see her WA status. The aim of this written satire is only for speaker's expression, to show her existence to her friends connected 
to WA network. There are many cases of indirect satire model which aim to show existence (satirize other people to show off something or speaker's goodness) for Madurese people in Situbondo. Commonly, it is expressed by teenagers who need social recognition.

Most utterances with abusive sarcasm through social media, mostly done by women and directed at women. This example is the same as the sample data on the threat and affirmation model where the status is made by young women and addressed to a woman. This is possible because in Madura culture women experience a lot of violence (physical and psychological). ${ }^{13}$ The dominance of men in the cultural space of the Madurese community often makes a woman's position subordinate and confined. That expression often overflows in the space of social media which tends to be free and sporadic, so that the situation can be conveyed and channeled. This is different from Madura men, that they tend to prefer to say dislike directly from the media that seems convoluted.

\section{e. Kiyai Quote Pattern}

\footnotetext{
13 Sarmini, "Ruang dan kultur Kekerasan Domestik: Pengalaman Perempuan Madura di Kemayoran Baru Surabaya". Humaniora, 20 No. 1 (2008), 38-50.
} 
Nasehat almarhum kiyai fawaid as'ad (alfateha) untuk beliau!! Semoga para santri/alumni /simpatisan sukorejo maupun W9 tidk terpengaruh dngan adu domba pelacur politik dalam kontestasi pilkada situbondo tahun ini...Beda pilihan itu sebagian daripada pesta DEMOKRASI..

Jek nyale calon laen...mon bede diantara salah satu pendukung nyale calon laen, berarti dia BODOH tentang Demokrasi..

\# KITA SITUBONDO

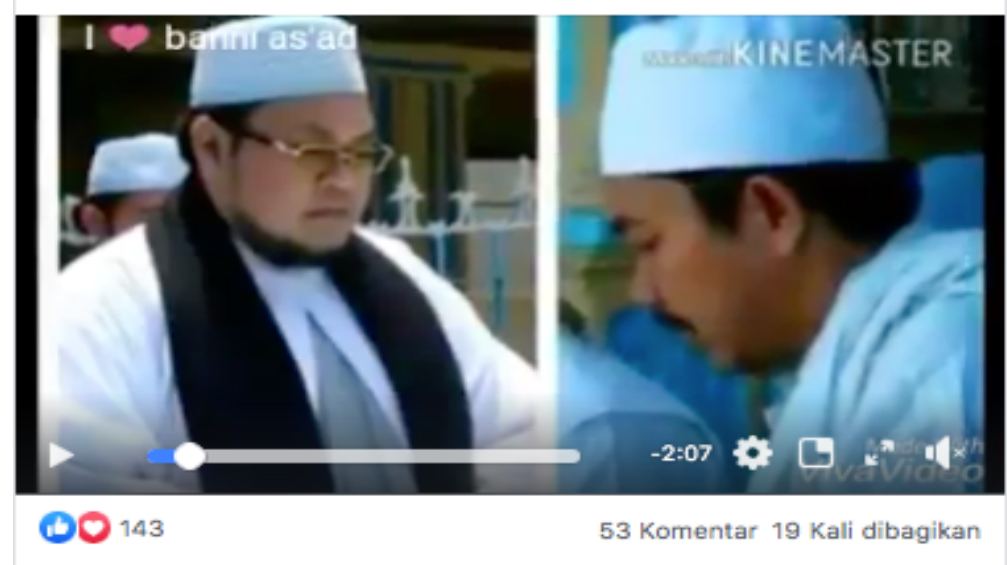

Picture. 9 Kiyai Quote

Source: Personal Documentation

"Jhâ' nyalè calon laèn, mon bâdâ diantara salah satu pendukung nyalè calon laen berarti dia BODOH tentang demokrasi"

Don't insult other candidates, if one of the supporters insults the other candidate, it means that he is stupid about democracy.

The context for the above critical statement is the expression stated by El Zain Ce, a member of the "Bursa Pemilihan Bupati dan Wakil Bupati" group on Facebook page. In 2020, Situbondo is preparing for the Regional Head election, and the group's page contains the campaign for candidate pairs who will advance in the 2020 Pilkada. Like a Facebook group page with minimal curation, there are also many hate speeches and hoaxes posted by fake accounts. El Zain Ce as one of the group members gave criticism to the supporters of the candidate pair 
who often insulted each other, and said sarcasm sentences that often caused chaos.

It should be explained that in Situbondo there are several religious figures (Kiyai) who are respected and respected by the community, including the sons and families of KHR. As'ad Syamsul Arifin, namely KHR. Kholil As'ad Syamsul Arifin, the caretaker of the Walisanga boarding school and KHR Ach. Azaim Ibrahimy, the caretaker of the Salafiyah Safi'yah Sukorejo Islamic boarding school. In previous elections, these two Islamic boarding schools were often used as the axis of opposing political power, to be precise when the late KHR. Fawaid As'ad is still caretaker of the Salafiyah Safi'iyah Sukorejo boarding school. On one occasion when the community began to split, KHR. Fawaid As'ad advised that they should not want to be pitted against each other for political interests. Islam, especially the NU congregation in Situbondo, should not become divided just because of matters of democratic parties, even to the point of insulting one another. The statement was recorded in an audio, which was later quoted and used by El Zain Ce to be posted on "Bursa Pemilihan Bupati dan Wakil Bupati Situbondo group.

El Zain Ce actually criticized by using the recording of Kiyai's statement, he reminded the public that acts of insulting each other because politics is an act of humiliation, even Kiyai forbids it. Generally, criticism with such a model is quite effective, given the views of the people in Situbondo which highly respect the figure of Kiyai.

\section{f. Lyrical and Poetic Pattern}




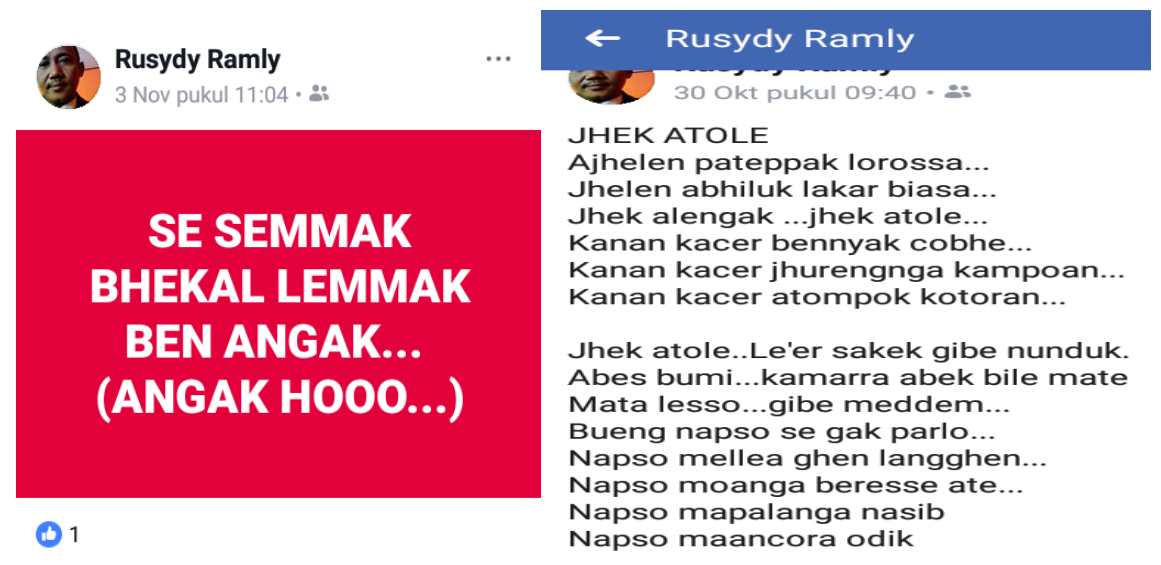

Picture 10. Lyrical and Poetic Pattern

Source: Personal Documentation

The last criticism model is using lyrical and poetic pattern. This kind of criticism model is quite favored by Madurese people in Situbondo. Most of Situbondo people know poetic practices (papareghân). Criticism by using papareghán and poetic model is criticism model acceptable to all people. Besides linguistically beautiful, this kind of criticism model also becomes entertainment for readers. So it is often when someone writes facebook status by using this model, then it will be responded by other social media users by using the same model like expressing each other poems.

\section{Discussions}

\section{Motive of Language Use}

It was explained before about language choice of criticism by Madurese people in Sitbondo in social media. Besides it has linguistic dimension, language behavior also has other dimensions like social, psychology and cultural dimension. Language behavior is not just activity to choose set of language code, but it is also related to social, psychological and cultural matters. ${ }^{14}$ Language behavior of person in

${ }^{14}$ Bambang Wibisono, Etnografi Komunikasi Dalam Penelitian Perilaku Berbahasa (Jember: Jember University Press, 2007), 15. 
society is tied to values and rules applied in society. Therefore, by means of behavior acted, it can be known who and what social group the person comes from.

\section{Motives of Choice of Language Code and Mixed Code}

Madurese people in Situbondo are closely related to diglosia or multilingual factor. According to Fishman, diglosia is not only symptom in monolingual society, but also in multilingual society. ${ }^{15}$ Diglosia refers to language use according to each function in society. Diglosia does not only apply to difference of various $\mathrm{H}$ (High language) and L (Low language) in the same language, but it also applies to completely different language family, or two different language. In multilingual society like Situbondo, language commonly has different function and duty.

In Situbondo, language also defines degree and multiple differentiation of function or called as overlapping diglosia. In Situbondo, people use Indonesian and Madurese with various dialect and level of speech like Javanese language. In certain situation, Madurese is $\mathrm{H}$ language with certain dialect and Javanese is $\mathrm{L}$ language. In another situation, Madurese language becomes $\mathrm{L}$ and $\mathrm{H}$ is Indonesian or English. Therefore, Madurese language with dialect and certain level of speech has multiple functions, which is as $\mathrm{H}$ to Javanese and $\mathrm{L}$ to Indonesian and English.

A sample case is about use of Madurese and mixed language. If in Jember, Madurese people tend to use Indonesian and Javanese to interlocutors. ${ }^{16}$ Based on findings in the research field in Situbondo, Madurese people tend to use Madurese or mixed language (MadureseIndonesia) to person he/she knows. On the other side, in cultural events and tourism promotion organized by government, regional government even tends to use English language rather than Indonesian and Madurese

15 J. Holmes, An Introduction to Sociolinguistics (London: Longman Group UK Limited, 1997).

${ }^{16}$ Bambang Wibisono, Etnografi Komunikasi Dalam Penelitian Perilaku Berbahasa (Jember: Jember University Press, 2007), 49. 
language. This shows that there are certain function and role in using language to Madurese people in Situbondo.

Another example of motive to use Madurese language in low level (rude) is also because of motive of ethnic identity in order to accept easily to interlocutor and speaking convenience like Fina said (see the text of indirect satire) below

"I write status in WA is not for pompous, just only for status. A person I satirize cannot read it. I use Madurese language, yes because to make it easy to understand for my contact WA friends. Why must to use Indonesian language, it (Madurese) is easier to express what is in your heart. It can also use Indonesian language but need to think first, if using Madurese, just write, why must to think. My fellows surely understand what I mean. (Private communication. 27 $7^{\text {th }}$ November 2018)

Fina says that language use actually adjusts interlocutors, so critical message expressed can be right on target. Use of criticism in rude language is considered to be able to articulate expression and steam in the speaker's heart.

\section{Dimension of Ethnic Group}

As Tionghoa ethnic group in Pasuruan who choose to use Indonesian and mixed language to communicate to local people, ${ }^{17}$ this has the same case in Situbondo. Some minority ethnic community like Tionghoa and Arab also choose to communicate to local people by using Madurese or mixed language. Here are data sample in the form of criticism uploaded by a member of Arab ethnic people in Situbondo in media social status facebook.

${ }^{17}$ Bambang Wibisono, Etnografi Komunikasi Dalam Penelitian Perilaku Berbahasa (Jember: Jember University Press, 2007), 19-22. 


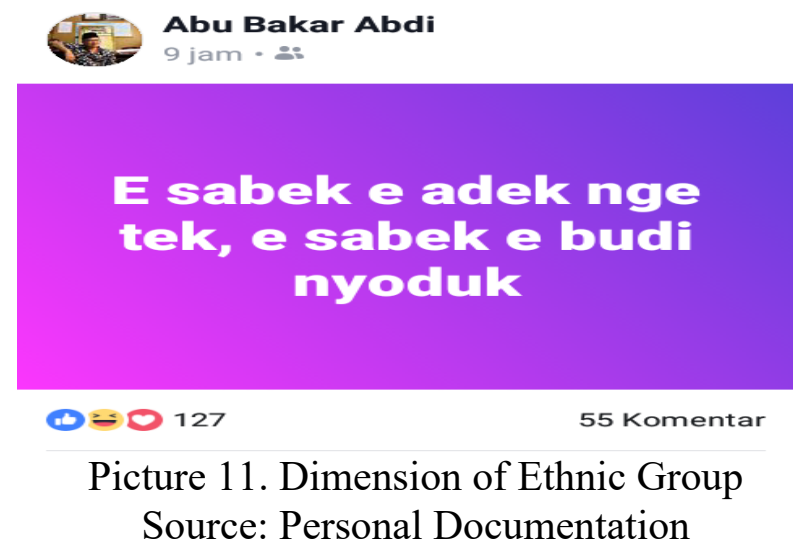

It needs to explain that a user of the status is a part of Arab ethnic community in Sitibondo. Use of Madurese as criticism language in social media contains meaning that the speaker also identifies as a part of Situbondo people. Self-identification is shown by using language spoken by dominant people in Situbondo.

\section{Psychological and Cultural Motives}

Speaker's motives to use choice of language code and expression style are also dominated by psychological and cultural factors. In Madurese society, communication patterns are largely determined by cultural aspects that pay attention to social status, roles and economic status. ${ }^{18}$ Speech participants will consider communication strategies, what language codes are considered appropriate or needed to convey messages to the speech partners. For example, santri speech participants need high-level Madurese language codes to communicate to the chaplain as the most respected speech partner, and use Madurese language or mixed language to fellow santri relatives. Giles, develops meaning of accommodation theory in psychological perspective to linguistic and language behavior. ${ }^{19}$ According to him, accommodation

\footnotetext{
18 A. Haryono, "Pola Komunikasi Warga NU Etnis Madura Sebagai Refleksi Budaya Paternalistik”. Humaniora, 23, No. 2 (2011).

19 J. F. Hamers, Bilinguality and Bilingualism (Cambridge: Cambridge University
} 
theory says that pattern of language choice or various language in bilingual and multilingual society is related to wants and needs of speech participants (speaker and interlocutor). ${ }^{20}$ An example is in case of criticism expressed by Rusdi (see part of code of mixed language Madurese-English, humor, figurative and lyrical patterns). Here is Rusdi statement about use of language in his criticism.

"Yah, I often criticize people (government) that, I think, do not do things in the right or good way. When I see something strange, I put criticism. Criticism I raise intentionally is made comfy (funny and interesting) and triggers response of people to achieve its aim.” (Private communication, 28 November 2018)

Rusdi statement describes that choice of language code and various speech expression always consider aspect of interlocutor and cultural background of intended people. Rusdi can also use criticism by using Indonesian language explicitly, but in this context, there are psychological and cultural motives which make him respond by using Madurese and mixed language with unique style like humor (play), figurative and lyrical pattern. Choice of language used by Rusdi aims to make his criticism acceptable, interpreted and responded by intended group of people. Therefore, the aims (wants and needs) of his criticism are achieved. Motives of using expression speech with style of humor, figurative and lyrical pattern are for communication strategy in order to make it understandable, interesting, tickling and not making social conflict in society. Besides functioning as criticism in context of social media content, the criticism also functions as its own entertainment media for Madurese people in Situbondo, proven by crowd of activities to comment and respond by people.

\section{Formulation of Language Expressed by Informants}

Press, 1995).

${ }^{20}$ Bambang Wibisono, Etnografi Komunikasi Dalam Penelitian Perilaku Berbahasa (Jember: Jember University Press, 2007), 59. 
Here will be described in the table about various choice of language criticism in social media by Madurese people in Situbondo. The table contains choice of language, background context, motives of choice and people perception about the criticism.

\begin{tabular}{|c|c|c|c|}
\hline $\begin{array}{l}\text { Language } \\
\text { choice }\end{array}$ & Context & Motive & $\begin{array}{l}\text { People } \\
\text { Perception }\end{array}$ \\
\hline \multicolumn{4}{|c|}{ Mixed Code } \\
\hline $\begin{array}{l}\text { Madurese- } \\
\text { Indonesia }\end{array}$ & $\begin{array}{l}\text { Used as } \\
\text { expression of } \\
\text { formal and } \\
\text { semi-formal } \\
\text { criticism to } \\
\text { person or } \\
\text { group not very } \\
\text { close. It is } \\
\text { usually } \\
\text { expressed in } \\
\text { local group } \\
\text { Situbondo as } \\
\text { identity } \\
\text { signifier of } \\
\text { people of } \\
\text { Situbondo city } \\
\text { (many used) }\end{array}$ & $\begin{array}{l}\text { Regarded as } \\
\text { language } \\
\text { criticism } \\
\text { proper to } \\
\text { express in } \\
\text { formal and } \\
\text { semi-formal } \\
\text { context. } \\
\text { Regarded as } \\
\text { representation } \\
\text { of identity of } \\
\text { Madurese } \\
\text { people in } \\
\text { Situbondo } \\
\text { and } \\
\text { considered to } \\
\text { be better (H) } \\
\text { than using } \\
\text { native } \\
\text { Madurese } \\
\text { language (L). }\end{array}$ & $\begin{array}{l}\text { Criticism } \\
\text { using code of } \\
\text { mixed } \\
\text { language } \\
\text { Madurese- } \\
\text { Indonesian is } \\
\text { acceptable by } \\
\text { people, } \\
\text { because in } \\
\text { social reality, } \\
\text { mixed } \\
\text { language is } \\
\text { used in formal } \\
\text { and semi- } \\
\text { formal } \\
\text { context. } \\
\text { Criticism } \\
\text { avoided is } \\
\text { criticism } \\
\text { containing } \\
\text { hate speech, } \\
\text { sarcasm } \\
\text { sentence and } \\
\text { harassing } \\
\text { pride of } \\
\text { speaking } \\
\text { partner. }\end{array}$ \\
\hline
\end{tabular}




\begin{tabular}{|c|c|c|c|}
\hline $\begin{array}{l}\text { Madurese- } \\
\text { English }\end{array}$ & $\begin{array}{l}\text { Used to mock, } \\
\text { satirize and } \\
\text { ridicule } \\
\text { government } \\
\text { policy } \\
\text { carelessly } \\
\text { making tagline } \\
\text { in English. } \\
\text { It is also } \\
\text { usually used to } \\
\text { informal } \\
\text { criticism } \\
\text { (assumed to } \\
\text { have higher } \\
\text { social status } \\
\text { position, } \\
\text { because } \\
\text { English is } \\
\text { considered to } \\
\text { be high } \\
\text { language in } \\
\text { Situbondo). } \\
\text { (rarely used). }\end{array}$ & $\begin{array}{l}\text { English } \\
\text { language is } \\
\text { regarded as } \\
\text { high language } \\
\text { (H) rather } \\
\text { than } \\
\text { Madurese (L), } \\
\text { so use of } \\
\text { mixed } \\
\text { language } \\
\text { Madurese- } \\
\text { English seems } \\
\text { to be able to } \\
\text { show } \\
\text { different class } \\
\text { status in } \\
\text { society. } \\
\text { Besides, use } \\
\text { of mixed } \\
\text { language } \\
\text { Madurese- } \\
\text { English is } \\
\text { also used as } \\
\text { satire because } \\
\text { it looks } \\
\text { irregular } \\
\text { (disorder) in } \\
\text { its form. The } \\
\text { effect will } \\
\text { cause humor } \\
\text { and } \\
\text { entertaining } \\
\text { style. }\end{array}$ & $\begin{array}{l}\text { Criticism with } \\
\text { code of mixed } \\
\text { language } \\
\text { Madurese- } \\
\text { English is } \\
\text { acceptable by } \\
\text { Situbondo } \\
\text { people as long } \\
\text { as expressed } \\
\text { by not } \\
\text { offending the } \\
\text { speaking } \\
\text { partner. } \\
\text { For example } \\
\text { expressing } \\
\text { with humor } \\
\text { style. }\end{array}$ \\
\hline
\end{tabular}




\begin{tabular}{|c|c|c|c|}
\hline Humor Pattern & $\begin{array}{l}\text { Criticism with } \\
\text { humor pattern } \\
\text { is the most } \\
\text { frequently } \\
\text { used by } \\
\text { Madurese } \\
\text { people in } \\
\text { Situbondo. It is } \\
\text { usually used to } \\
\text { satirize } \\
\text { person/group } \\
\text { vaguely and } \\
\text { interestingly. } \\
\text { The aim is to } \\
\text { make the } \\
\text { criticized not } \\
\text { feel } \\
\text { embarrassed } \\
\text { and criticism } \\
\text { can be } \\
\text { expressed in a } \\
\text { good way. } \\
\text { (the many } \\
\text { used) }\end{array}$ & $\begin{array}{l}\text { Regarded as } \\
\text { closest to } \\
\text { daily } \\
\text { conversation } \\
\text { in Madurese } \\
\text { people in } \\
\text { Situbondo } \\
\text { known as } \\
\text { humorous and } \\
\text { playful. It is } \\
\text { regarded as } \\
\text { entertaining } \\
\text { and able to } \\
\text { melt a } \\
\text { complex } \\
\text { thing. }\end{array}$ & $\begin{array}{l}\text { Criticism with } \\
\text { humor pattern } \\
\text { is the most } \\
\text { acceptable } \\
\text { model of } \\
\text { criticism by } \\
\text { Madurese } \\
\text { people in } \\
\text { Situbondo. } \\
\text { This kind of } \\
\text { criticism has } \\
\text { been an } \\
\text { inevitable part } \\
\text { of daily life of } \\
\text { Madurese } \\
\text { people known } \\
\text { as humorous. }\end{array}$ \\
\hline $\begin{array}{l}\text { Figurative } \\
\text { pattern }\end{array}$ & $\begin{array}{l}\text { This kind of } \\
\text { criticism is } \\
\text { used to satirize } \\
\text { person, group } \\
\text { or system with } \\
\text { model of } \\
\text { metaphoric } \\
\text { language. Use } \\
\text { of criticism } \\
\text { with this } \\
\text { figurative }\end{array}$ & $\begin{array}{l}\text { It can disguise } \\
\text { subject/object } \\
\text { of criticism so } \\
\text { it can } \\
\text { minimalize } \\
\text { occurrence of } \\
\text { social } \\
\text { conflict. } \\
\text { Besides, this } \\
\text { style is also } \\
\text { considered to }\end{array}$ & $\begin{array}{l}\text { Criticism with } \\
\text { this figurative } \\
\text { model is } \\
\text { criticism } \\
\text { acceptable by } \\
\text { Madurese } \\
\text { people in } \\
\text { Situbondo, as } \\
\text { long as the } \\
\text { content does } \\
\text { not contain }\end{array}$ \\
\hline
\end{tabular}




\begin{tabular}{|c|c|c|c|}
\hline & $\begin{array}{l}\text { pattern is } \\
\text { usually used to } \\
\text { disguise object } \\
\text { of criticism. } \\
\text { (rarely used) }\end{array}$ & $\begin{array}{l}\text { have aesthetic } \\
\text { and } \\
\text { entertaining } \\
\text { impression. }\end{array}$ & $\begin{array}{l}\text { sarcasm } \\
\text { sentence and } \\
\text { offend pride } \\
\text { and social } \\
\text { status of } \\
\text { person. }\end{array}$ \\
\hline $\begin{array}{l}\text { Threatening and } \\
\text { affirmative } \\
\text { pattern }\end{array}$ & $\begin{array}{l}\text { This criticism } \\
\text { is used in the } \\
\text { most } \\
\text { emotional } \\
\text { context, } \\
\text { usually } \\
\text { expressed } \\
\text { when the } \\
\text { speaker is } \\
\text { harmed and } \\
\text { oppressed. In } \\
\text { reality, this } \\
\text { kind of } \\
\text { criticism is } \\
\text { founded many } \\
\text { in social } \\
\text { media, and } \\
\text { average } \\
\text { speakers are } \\
\text { teenagers or } \\
\text { people who } \\
\text { just know } \\
\text { social media. } \\
\text { Habit in } \\
\text { wreaking } \\
\text { feeling } \\
\text { expressively in } \\
\text { real world is } \\
\text { finally brought }\end{array}$ & $\begin{array}{l}\text { Regarded as } \\
\text { the most } \\
\text { capable to } \\
\text { express } \\
\text { speaker } \\
\text { emotion } \\
\text { clearly, } \\
\text { openly and } \\
\text { outspoken. } \\
\text { Uttering } \\
\text { something } \\
\text { outspoken is } \\
\text { in accordance } \\
\text { with habit of } \\
\text { Madurese } \\
\text { people in } \\
\text { Situbondo. }\end{array}$ & $\begin{array}{l}\text { This kind of } \\
\text { criticism is } \\
\text { model of } \\
\text { criticism } \\
\text { unacceptable } \\
\text { by Madurese } \\
\text { people in } \\
\text { Situbondo } \\
\text { because it } \\
\text { commonly } \\
\text { contains } \\
\text { sarcasm } \\
\text { sentence and } \\
\text { full of hate } \\
\text { speech. }\end{array}$ \\
\hline
\end{tabular}




\begin{tabular}{|c|c|c|c|}
\hline & $\begin{array}{l}\text { in reality of } \\
\text { social media. } \\
\text { (many used) }\end{array}$ & & \\
\hline $\begin{array}{l}\text { Direct satire } \\
\text { pattern }\end{array}$ & $\begin{array}{l}\text { This criticism } \\
\text { is usually used } \\
\text { by speaker } \\
\text { who has close } \\
\text { relationship to } \\
\text { satirized } \\
\text { subject. For } \\
\text { example } \\
\text { someone } \\
\text { satirizes } \\
\text { his/her } \\
\text { relatives or } \\
\text { neighbors. In } \\
\text { social reality, } \\
\text { direct satire is } \\
\text { common, but it } \\
\text { becomes } \\
\text { unusual when } \\
\text { it shows to } \\
\text { public in social } \\
\text { media, because } \\
\text { it can make } \\
\text { criticized } \\
\text { people feel } \\
\text { ashamed. } \\
\text { (many used) }\end{array}$ & $\begin{array}{l}\text { Regarded as } \\
\text { something } \\
\text { common and } \\
\text { normal for } \\
\text { Madurese } \\
\text { people in } \\
\text { Situbondo. }\end{array}$ & $\begin{array}{l}\text { A kind of } \\
\text { criticism with } \\
\text { direct satire is } \\
\text { a kind of } \\
\text { criticism } \\
\text { usually used } \\
\text { by Madurese } \\
\text { people in } \\
\text { Situbondo. } \\
\text { Therefore, this } \\
\text { kind of } \\
\text { criticism is } \\
\text { still acceptable } \\
\text { by people. } \\
\text { This criticism } \\
\text { becomes } \\
\text { problems } \\
\text { when satire } \\
\text { content is too } \\
\text { harsh for using } \\
\text { sarcasm } \\
\text { sentence and } \\
\text { containing } \\
\text { factor of } \\
\text { lowering } \\
\text { people's pride }\end{array}$ \\
\hline $\begin{array}{l}\text { Indirect satire } \\
\text { pattern }\end{array}$ & $\begin{array}{l}\text { This criticism } \\
\text { in reality of } \\
\text { Madurese } \\
\text { people in } \\
\text { Situbondo is }\end{array}$ & $\begin{array}{l}\text { Considered to } \\
\text { be able to } \\
\text { become space } \\
\text { to express } \\
\text { heart's }\end{array}$ & $\begin{array}{l}\text { This kind of } \\
\text { indirect satire } \\
\text { is criticism } \\
\text { usually used } \\
\text { by Madurese }\end{array}$ \\
\hline
\end{tabular}




\begin{tabular}{|c|c|c|c|}
\hline & $\begin{array}{l}\text { also often } \\
\text { used. It is } \\
\text { usually used to } \\
\text { criticize person } \\
\text { via third } \\
\text { person } \\
\text { (indirect). In } \\
\text { social media, } \\
\text { this pattern is } \\
\text { also still used, } \\
\text { like an } \\
\text { example of } \\
\text { WA status of } \\
\text { Fina. Besides } \\
\text { for satirizing } \\
\text { person, satire } \\
\text { pattern } \\
\text { (indirect) is } \\
\text { also } \\
\text { interpreted as } \\
\text { speakers' } \\
\text { expression to } \\
\text { show their } \\
\text { existence. } \\
\text { (many used) }\end{array}$ & $\begin{array}{l}\text { feeling, steam } \\
\text { and } \\
\text { annoyance to } \\
\text { satirized } \\
\text { person. } \\
\text { Besides, it is } \\
\text { for means of } \\
\text { self-existence } \\
\text { and looking } \\
\text { for social } \\
\text { recognition. }\end{array}$ & $\begin{array}{l}\text { people in } \\
\text { Situbondo. } \\
\text { Therefore, this } \\
\text { kind of } \\
\text { criticism is } \\
\text { still acceptable } \\
\text { by people. } \\
\text { This criticism } \\
\text { becomes } \\
\text { problem when } \\
\text { satire content } \\
\text { is too harsh for } \\
\text { using sarcasm } \\
\text { sentence and } \\
\text { containing } \\
\text { factor of } \\
\text { lowering } \\
\text { people's pride. }\end{array}$ \\
\hline $\begin{array}{l}\text { Kiyai Quote } \\
\text { Pattern }\end{array}$ & $\begin{array}{l}\text { This criticism } \\
\text { is an } \\
\text { alternative } \\
\text { criticism } \\
\text { commonly } \\
\text { used to resolve } \\
\text { group disputes } \\
\text { on social } \\
\text { media. (rarely } \\
\text { used) }\end{array}$ & $\begin{array}{l}\text { It is } \\
\text { considered } \\
\text { effective to be } \\
\text { carried out } \\
\text { and to resolve } \\
\text { disputes in } \\
\text { society, } \\
\text { considering } \\
\text { that the } \\
\text { Madurese } \\
\text { community }\end{array}$ & $\begin{array}{l}\text { Some people } \\
\text { consider this } \\
\text { criticism to be } \\
\text { effective and } \\
\text { productive } \\
\text { because it } \\
\text { rarely causes } \\
\text { prolonged } \\
\text { conflict. }\end{array}$ \\
\hline
\end{tabular}




\begin{tabular}{|c|c|c|c|}
\hline & & $\begin{array}{l}\text { still views } \\
\text { Kiai as a } \\
\text { central figure } \\
\text { in society. }\end{array}$ & \\
\hline $\begin{array}{l}\text { Lyrical/Poetical } \\
\text { Pattern }\end{array}$ & $\begin{array}{l}\text { This criticism } \\
\text { is used by } \\
\text { speaker to } \\
\text { person, group } \\
\text { or system by } \\
\text { using sentence } \\
\text { which has } \\
\text { aesthetic value } \\
\text { in the form of } \\
\text { poem, lyric or } \\
\text { narration. The } \\
\text { aim is to make } \\
\text { criticized } \\
\text { object/subject } \\
\text { be able to } \\
\text { accept } \\
\text { criticism } \\
\text { expressed in a } \\
\text { good way. } \\
\text { Besides, this } \\
\text { kind of } \\
\text { criticism also } \\
\text { has educative } \\
\text { and } \\
\text { entertaining } \\
\text { factor for } \\
\text { netizen who } \\
\text { read it. } \\
\text { (rarely used) }\end{array}$ & $\begin{array}{l}\text { Regarded as } \\
\text { the real } \\
\text { tradition } \\
\text { owned by } \\
\text { Madurese } \\
\text { people like } \\
\text { tradition of } \\
\text { paparèkan. } \\
\text { This tradition } \\
\text { begins to be } \\
\text { abandoned, so } \\
\text { making it as } \\
\text { criticism } \\
\text { media is a } \\
\text { way to } \\
\text { conserve it. }\end{array}$ & $\begin{array}{l}\text { This kind of } \\
\text { criticism is } \\
\text { criticism } \\
\text { model } \\
\text { acceptable by } \\
\text { people. } \\
\text { Because } \\
\text { beside of } \\
\text { containing } \\
\text { criticism } \\
\text { inside, there } \\
\text { are also } \\
\text { aesthetic, } \\
\text { educative and } \\
\text { entertaining } \\
\text { values. In } \\
\text { terms of } \\
\text { content, } \\
\text { criticism is not } \\
\text { limited only } \\
\text { for criticized } \\
\text { object/subject } \\
\text { but it also } \\
\text { becomes } \\
\text { shared } \\
\text { reflection for } \\
\text { the readers. }\end{array}$ \\
\hline
\end{tabular}




\section{Conclusion}

Madurese people in Situbondo are group of 'lay' people on internet media (social media). Incomprehension in using social media often causes problems in society. This research succeeds to find some field findings related to criticism behavior of Madurese people in Situbondo in social media. Some findings are 1) aspect of language choice: Situbondo people express criticism in social media by using code of Madurese and mixed language, Madurese - Indonesian and Madurese - English, and express them through some patterns which are humor, figurative, threatening and affirmative, direct and indirect satire, Kiyai quote and lyrical/poetic; 2) aspects of motive in language choice: some motives which become background in choosing language code in expressing criticism are influenced by aspects of hierarchy language in context of diglosia society, politic of identity, dimension of ethnic group and psychological and cultural motives. Formulation of these findings explains that most of criticism model by Madurese people in Situbondo by means of social media is manifestation of habit in expressing criticism in real world. The one avoided is criticism model which uses sarcasm sentence, contains hate speech, offends pride, social status, family and feeling of interlocutors. Expressive and outspoken criticism in social media are considered to be dangerous and unacceptable by people because they create 'floating' (unclear) interpretation and potential to be misinterpreted. While some acceptable criticism are criticism model expressed with code of fine language and expressed with patterns of humor, figurative, fine satire and lyrical/poetic.

\section{Bibliography}

Hamers, J.F. Bilinguality and Bilingualism. Cambridge: Cambridge University Press, 1995.

Haryono, A. "Pola Komunikasi Warga NU Etnis Madura Sebagai Refleksi Budaya Paternalistik." Jurnal Humaniora 23, No. 2 (2011).

Hidayatullah, P. Dangdut Madura Situbondoan. Yogyakarta: Diandra Kreatif, 2017.

Holmes, J. An Introduction to Sociolinguistics. London: Longman Group UK Limited, 1997. 
Marzali, A. Apakah Etnografi, dalam Metode Etnografi. Yogyakarta: Tiara Wacana, 1997.

Santoso, T. "Kajian Sosiobudaya Kumpulan Sajak Madura, "Akulah Darahmu" Karya D. Zawawi Imron". Jurnal Humaniora, 16, No.3 (2004), 313-319.

Sarmini. "Ruang dan kultur Kekerasan Domestik: Pengalaman Perempuan Madura di Kemayoran Baru Surabaya". Jurnal Humaniora, 20, No. 1 (2008), 38-50.

Savile-Troike, M. The Ethnography of Communication. New York: Basil Blackwell Ltd, 1989.

Soegianto. Unda-Usuk Bahasa Madura. Jakarta: Pusat Pembinaan dan Pengembangan Bahasa Departemen Pendidikan dan Kebudayaan, 1997.

Sofyan, A. Variasi, Keunikan, dan Penggunaan Bahasa Madura. Surabaya: Balai Bahasa Surabaya, 2008.

Spradley, J. P. Participant Observation. New York: Hold, Rinehart and Winston, 1980.

Sukardi, A. Kasusastraan Madura Kembang Sataman. Jember: Dinas Pendidikan Kabupaten Jember, 2001.

Wibisono, B. Etnografi Komunikasi Dalam Penelitian Perilaku Berbahasa. Jember: Jember University Press, 2007.

Wibisono, B. "Faktor Penentu Pemilihan Varian Bahasa oleh Multibahasawan Etnis Madura di Jember dalam Obrrolan". Jurnal Humaniora 19, no. 1 (2007): 52-61, https://doi.org/10.22146/ jh.v19i1.891. 